\title{
INEFFECTIVENESS OF WRAPPED FLOWER IN INHIBITING CROSS-FERTILIZATION IN PIGEONPEA*
}

\author{
K. B. SAXENA, D.SHARMA and D.G.FARIS
}

International Crops Research Institute for the Semi-Arid Tropics. Patancheru 502.324. Andhra Pradesh. India

Received 15 April 1986

INDEX WORDS

Cajanus cajan, pigeonpea, cross-fertilization, out-crossing, wrapped flower.

SUMMARY

The wrapped flower character has been reported to inhibit out-crossing in pigeonpea in Aust ralia. However, one of the wrapped flower lines gave an average of about $16 \%$ out-crossing at ICRISAT Center near Hyderabad, India. This level of out-crossing was not different from that in cultivars having normal (unwrapped) flowers. This suggests that the wrapped flower trait is not a dependable character for reducing out-crossing in pigeonpea.

\section{INTRODUCTION}

BYTH et al. (1982) reported a floral modification in pigeonpea (Cajanus cajan (L.) MiL.LSP.), which is characterized by the wrapping or overlapping of standard margins in the bud. It ensured a high level of self-fertilization at the University of Queensland, Brisbane in Australia. They reported less than $2 \%$ out-crossing in the wrapped flower cv. Royes and up to $30 \%$ in the normal unwrapped flower lines.

In India, about $20 \%$ out-crossing has been reported at various locations (HowARD et al., 1919; Mahta \& Dave, 1931; Deshmukn \& Rekhi, 1963; Bhatia et al., 1981) in normal (unwrapped) flower cultivars. However, because of the high cost of controlling pollination, most breeders maintain pigeonpea cultivars as if the crop is mainly self-pollinated. Incorporation of a mechanism preventing out-crossing such as the wrapped flower character in parents and breeding populations would be useful in developing pure breeding lines and the maintenance of promising genotypes. Before depending on wrapped flower to provide selfing in the breeding program at ICRISAT, a study was undertaken to determine the effectiveness of this characters in inhibiting out-crossing under the environmental conditions at ICRISAT near Hyderabad, India.

\section{MATERIALS AND METHODS}

The wrapped flower cv. Royes was introduced to ICRISAT from Australia in 1981.

* ICRISAT Journal Article No. 578. 
In the following year its bulk seed was planted in $4 \mathrm{~m}$ long single rows at 10 locations within a six-hectare block that had been planted with indeterminate genotypes. Five random plants from each of the 10 plots were harvested. Due to extensive pod-borer damage only 16 plants produced enough seeds for tests. The 16 progenies were grown in $4 \mathrm{~m}$ long four-row plots in 1983. The determinate growth habit of cv. Royes is recessive to the indeterminate habit of the other genotypes that were grown in the field. Therefore, the extent of out-crossing in 'Royes' was determined by counting the number of indeterminate plants in each progeny.

\section{RESULTS AND DISCUSSION}

Counts indicated that natural out-crossing per plant ranged from $9.2^{\circ}$, to $21.4^{4} \%$, averaging $15.5 \%$. Experiments to determine the extent of out-crossing using a stem colour marker in a genotype with normal unwrapped flowers had shown over $20 \%$ out-crossing at ICRISAT Center (BHATIA et al., 1981). Thus it is inferred that out-crossing in wrapped and unwrapped flowered lines did not differ substantially at ICRISAT in contrast to the large differences reported by BYrH et al. (1982), in Australia.

Many insect species are capable of pollinating pigeonpea (ONIM, 1981). In Australia Apis mellifera is a major pollinating insect responsible for cross-fertilization of pigeonpea (BYTH et al., 1982) while at ICRISAT Center Megachile spp. have been reported to be the most effective pollinators (WILLIAMs, 1977). It appears that Apis mellifera is unable to work on the wrapped flowers at the critical pre-anthesis stage in Australia, while the activity of the pollinating insects at ICRISAT may not be hampered by wrapping or interlocking of the standard margins.

Besides the difference of pollinating insect species in the the two environments, climatic conditions in terms of humidity and temperature are also quite different. The Redland Bay farm in Queensland, Australia is located in a coastal area, where relative humidity and mean temperature at the time of flowering range from $56-72 \%$ and from 16 to $28^{\circ} \mathrm{C}$ respectively, in contrast to 43 to $69 \%$ relative humidity and 28 to 32 " $\mathrm{C}$ mean temperature at the ICRISAT Center.

KREITNER \& SORENSEN (1985) have reported that in Medicago species low humidity and high temperatures help in loosening the interlocking mechanism of the standard and keel petals, since the overhanging edges slide free of one another after loss of cell turgidity. In the case of pigeonpea a similar loosening of the interlocking mechanism of the standard petal under the low humidity and high temperatures at Hyderabad may facilitate the entry of insects resulting in a similar degree of out-crossing in unwrapped and wrapped flowers.

These observations indicate that the modification of floral morphology reported by BYTH et al. (1982), where the standard petal margins of floral buds are strongly convolute, is unable to inhibit out-crossing in pigeonpea under all conditions. Therefore, this character has limited value for ensuring genetic purity of pigeonpea stocks in the hot dry areas of India. Furthermore, the study suggests that for a better understanding of the effect of environment and of the pollinating insects on out-crossing in a wrapped flower cultivar, it is desirable to conduct such studies under well described vector and environment conditions. 


\section{REFERENCES}

Bhatia, G. K., S. C. Gupta, J. M. Green \& D. Sharma, 1981. Estimates of natural cross-pollination in Cajanus cajan (L.) MillsP.: Several experimental approaches. Proc. Intl. Workshop on Pigeonpeas, 15-19 Dec. 1980. ICRISAT Center, Vol. 2: 129-136. Patancheru, A.P. 502 324, India. International Crops Research Institute for the Semi-Arid Tropics.

Byth, D. E., K. B. SaXena \& E. S. Wallis, 1982. A mechanism for inhibiting cross-fertilization in pigeonpea (Cajanus cajan [L.]. MiLlsP.). Euphytica 31: 405-408.

Deshmukh, N. Y. \& S. S. Rekhl, 1963. Study of natural cross-pollination in pigeonpeal (Cajumias cajan [L.] MillsP.). Proc. Bihar Academy of Agric. Sci. 8-9:135-139.

Howard, A., G. L. C. Howard \& A. R. Khan, 1919. Studies in the pollination of Indian crops. I. Memoirs, Dept. of Agric. India (Botanical series) 10: 195-200.

Kreitner, G. L. \& E. L. SOREnSEn, 1985. Structure of the kecl locking mechanism in insect-pollinated and self-pollinated alfalfa species. Crop Sci. 25: 631-634.

Mahta, D. N. \& B. B. Dave, 1931. Studies in Cajanus indicus. Memoirs, Dept. of Agric. India (Botanical series) 19: 1-25.

ONim, J. F. M., 1981. Pigeonpea improvement in Kenya. Proc. Intl. Workshop on Pigeonpeas, 1519 Dec. 1980. ICRISAT Center, Vol. 1: 427-436. Patancheru, A.P. 502 324. India. International Crops Rescarch Institute for the Semi-Arid Tropics.

WiLliams, I. H., 1977. Behaviour of insects foraging on pigeonpea (Cajanus cajan (L.) MIL.L.sP.) in India. Trop. Agric. 54: 353-363. 